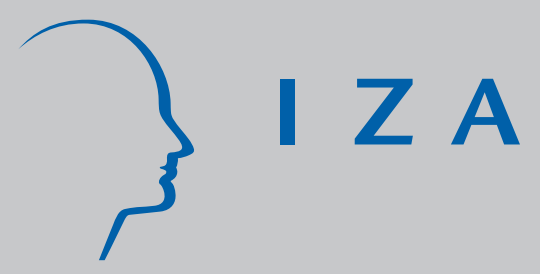

IZA DP No. 545

The Role of Background Factors for Reading Literacy: Straight National Scores in the PISA 2000 Study

Michael Fertig

Christoph M. Schmidt

August 2002 


\title{
The Role of Background Factors for Reading Literacy: Straight National Scores in the PISA 2000 Study
}

\author{
Michael Fertig \\ University of Heidelberg and IZA Bonn \\ Christoph M. Schmidt \\ University of Heidelberg, CEPR, and IZA Bonn \\ Discussion Paper No. 545 \\ August 2002 \\ IZA \\ P.O. Box 7240 \\ D-53072 Bonn \\ Germany \\ Tel.: +49-228-3894-0 \\ Fax: +49-228-3894-210 \\ Email: iza@iza.org
}

This Discussion Paper is issued within the framework of IZA's research area Evaluation of Labor Market Policies and Projects. Any opinions expressed here are those of the author(s) and not those of the institute. Research disseminated by IZA may include views on policy, but the institute itself takes no institutional policy positions.

The Institute for the Study of Labor (IZA) in Bonn is a local and virtual international research center and a place of communication between science, politics and business. IZA is an independent, nonprofit limited liability company (Gesellschaft mit beschränkter Haftung) supported by the Deutsche Post AG. The center is associated with the University of Bonn and offers a stimulating research environment through its research networks, research support, and visitors and doctoral programs. IZA engages in (i) original and internationally competitive research in all fields of labor economics, (ii) development of policy concepts, and (iii) dissemination of research results and concepts to the interested public. The current research program deals with (1) mobility and flexibility of labor, (2) internationalization of labor markets, (3) welfare state and labor market, (4) labor markets in transition countries, (5) the future of labor, (6) evaluation of labor market policies and projects and (7) general labor economics.

IZA Discussion Papers often represent preliminary work and are circulated to encourage discussion. Citation of such a paper should account for its provisional character. A revised version may be available on the IZA website (www.iza.org) or directly from the author. 
IZA Discussion Paper No. 545

August 2002

\section{ABSTRACT \\ The Role of Background Factors for Reading Literacy: Straight National Scores in the PISA 2000 Study* $^{*}$}

Based on the individual-level data of the PISA 2000 study, this note provides a detailed econometric analysis of the way that reading test scores are associated with individual and family background information and with characteristics of the school and class of the 15 to 16 year old respondents to the survey. Based on our quantile regressions, we interpret the national performance scores conditional on these observable characteristics, as the reflection of different education systems. Our findings suggest that US students, particularly those in the lower quantiles, are served relatively unsatisfactorily by their system of education. Moreover, part of the potential for improvement seems to involve measurable aspects which could be altered and monitored easily.

JEL Classification: $\quad$ 121, 128

Keywords: reading literacy, school resources, quantile regression

Michael Fertig

Department of Economics (Econometrics)

University of Heidelberg

Grabengasse 14

69117 Heidelberg

Germany

Fax: +49 6221543640

Email: fertig@uni-hd.de

\footnotetext{
* The authors are grateful to Georgios Tassoukis for his valuable help with the data and Jan Brenner for research assistance.
} 


\section{Introduction}

The way in which nations try to mold their young minds and talents into productive young adults differs widely across the OECD. A plethora of education systems employs different organizational structures and educational tools with varying intensity. The extent to which this really makes a difference is a topic of perpetual interest. Within the United States, researchers intensely debate the role of school quality for educational attainment and subsequent success in the labor market (see e.g. CARD AND KruEger (1992) and (1996), Coleman (1966) and HANusheK (1986)). International studies (see e.g. BARRO AND LEE (2001)) directly compare educational investment. Studies of migrant performance (see e.g. BORJAS (1985)) emphasize the different preparation of immigrants from distinct origin countries for the US labor market.

Yet, it is very difficult to compare the comparable across countries. While it might be straightforward to ascertain information about inputs and organizational approaches, and while it might also be a convincing identification assumption to presume identical distributions of cognitive abilities of any cohort of newborns, it is the comparison of outcomes across economies that is so difficult. After all, graduates from the education system compete in vastly different labor markets. Similarly, the comparison of labor market achievements of US graduates with those of migrants to the US would be problematic as well. Finally, even globally conducted tests such as the Graduate Record Examination (GRE) cannot really provide such a comparison, since this test is part of the "testing culture" only for American-trained students, it does not collect a satisfactory set of background information, and it is typically taken only by prospective academics.

By contrast, the world-wide "OECD Programme for International Student Assessment" (PISA 2000), held the promise to deliver the data for a meaningful international comparison. It was designed by eminent specialists in pedagogical issues with the aim of measuring practical knowledge in math, science and reading. The study induced quite different reactions throughout the participating countries. Whereas, for instance, the British were quite satisfied with the results of their students (see e.g. The Economist, December 8, 2001), Americans showed themselves rather disappointed (see e.g. The New York Times, December 4, 2001) and Germans were shocked (chose any newspaper of this time period you can find).

In the aftermath of the report (OECD (2002)) the PISA 2000 examination has initiated an intense discussion on the causes of these results and the consequences to be drawn. This reaction is astounding, however. After all, the results presented by the report consist by and large of country averages which do not control for any other covari-

ate of individual student achievement. Specifically, whether education systems operate under similar or vastly different conditions regarding (family) background and intergenerational skill transmission, has not been explored. There has not been any serious attempt to compare comparable students across countries. Yet, the the publicly available background information (http://www.pisa.oecd.org) collected in PISA 2000, family and individual characteristics and a rich set of school-related variables allows for a deeper analysis.

This note, therefore, aims at providing some more detailed information on the cor- 
relates of the reading performance of students in PISA 2000. By providing conditional national performance scores, we hope to identify that part of international differences attributable to genuine differences in education systems. The next section briefly describes the design of the PISA 2000 study. Section 3 then discusses the econometric approach chosen in this paper, an individually based quantile regression analysis of the reading literacy test score on a set of individual characteristics, family background information, as well as class and school characteristics. Section 4 reports the empirical finding of the mean as well as the quantile regressions and the final section discusses their implications.

\section{The Design of PISA 2000}

The PISA 2000 target population are 15 to 16 year old students enrolled in an educational institution at the time of the survey (the first half of 2000). The primary sample unit, however, were schools. In a second step, in every school a random sample of students from the target population was drawn resulting in a stratified cluster sample. The examination conducted among the students in the sample consisted of a reading, math and science literacy test. Furthermore, a wide variety of background information on the students was collected by student questionnaires. Among this individual information is the family background of the student, his or her attitudes towards visiting school, his or her learning strategy, a self-assessment of reading pleasure etc. Furthermore, the study also conducted a interviews among the principals of the respective schools in order to collect information on the school resources, the number of teachers in the school, the principles of selecting students etc.

The particular test score of an individual student is not the direct share of correct an-

swers. Rather, it is computed based on a procedure originating in Item Response Theory (see e.g. Hambleton And Swaminathan (1989)). Calculated scores are weighted averages of the correct responses to all questions of a specific category (e.g. reading literacy) with the difficulty of the question serving as weight (see e.g. WARM (1989)). These individual test scores are standardized in a subsequent step so that the unconditional sample mean of the PISA 2000 scores equals 500 and their unconditional sample standard error equals 100. The dependent variable in our analysis is the reading score of PISA 2000, since this part of the study requires the most know-how and the least know-that compared to the math and science part.

\section{Country Differences in Individual Achievement}

To assess the impact of institutional differences in school systems it is necessary to compare the test score of comparable individual students from the different countries involved. Specifically, since educational achievement is an inherently individual phenomenon, and exhibits considerable persistence across generations it is necessary to control for individual characteristics and family background in analyzing individual differences in test scores. Furthermore, the school and class specific information provide a first, albeit incomplete, picture of the tangible aspects of institutional differences in school systems across the 
participating countries. Institutional differences would tend to manifest themselves in the estimated impact of the school characteristics, while an unexplained remainder would be expressed as the differences in the national scores, that is the coefficients of the country indicators.

Our explanatory variables are described in detail in Table A1 in the Appendix and comprise individual and family background variables as well as class and school characteristics $^{1}$. TABLE A2 in the Appendix reports some descriptive statistics of the PISA 2000 dataset. Due to students with missing observations for some variables that were deleted from the sample, the unconditional sample mean of the reading literacy is 502.921 instead of 500 and the sample standard error is 98.098 instead of 100 .

The PISA 2000 study ascertains a wide variety of individual information regarding the participating students. There is a set of questions asking for a self-assessment of e.g. the pleasure in reading or the strategy of studying. However, these factors are in all likelihood endogenous outcomes affected by the same determinants as the dependent variable itself. For instance, for the self-assessed pleasure in reading it could be imagined easily that students who score high also perceive reading as a pleasure and vice versa.

Finally, we utilize quantile regression techniques to infer on the determining factors of reading literacy. This technique, introduced by KoEnKer AND BASSETT (1978) has found many empirical applications in different fields in recent years (see e.g. CHAMBerlain (1994), Eide And Showalter (1998), Fitzenberger (1999) or Levin (2001)). Quantile regression aims at providing an exhaustive analysis of the effect of the explanatory variables on the complete conditional distribution of the test score. Contrary to the usual OLS mean regression, the most prominent quantile regression, i.e. the median regression estimator, minimizes the sum of absolute errors instead of squared errors as in the usual OLS (mean) regression. Correspondingly, all other conditional quantile functions minimize an asymmetrically weighted sum of absolute errors.

Our analysis proceeds in three steps. A first series of quantile regressions estimates unconditional national performance scores - specified in deviation to the corresponding US quantile. These scores are our benchmark, basically replicating the results of the OECD (2002) report. In a second step, we further introduce all available individual and background characteristics into our quantile specifications. Estimated conditional national scores now capture how successfully different countries' education systems serve the cognitive development of students who are comparable in terms of their observable individual characteristics. Finally, a third set of quantile regressions additionally includes school and class characteristics. The estimated relative national scores now reflect differ-

\footnotetext{
${ }^{1}$ Many papers in the received literature stress the importance of school resources for the performance of students in the labor market after finishing school (see e.g. CARD AND KRUEGER (1992) and (1996)). One very prominent measure in this literature is the pupil-teacher-ratio. Unfortunately, we are not able to apply this ratio in our analysis as an explanatory factor as well since the necessary information on students and teachers is missing for all Canadian schools in the sample. Yet, Canada is the country with the most individual students attending the test in our sample. Therefore, we are hesitant to remove all Canadian participants from the sample, only to be able to apply the pupils-teacher-ratio as an additional regressor. However, a sensitivity analysis without Canada demonstrated that results do not change qualitatively if Canadian students are not considered.
} 
ences in the intangible aspects of the education systems.

\section{Empirical Results}

An inspection of the estimated unconditional national performance scores - expressed in deviation to the performance of US students in the same quantile - demonstrates that in terms of reading ability students of many countries are performing statistically significant better than US students. These results confirm the OECD (2002) report, hold throughout all quantiles without exception and are therefore not reported separately here. Among the top scorers are students from Finland, Korea and Australia, whereas the students from Brazil, Mexico, Poland, and Russia perform particularly poorly. Yet, such unconditional figures cannot be used to assess the relative performance of systems in which students typically originate from educated parents as compared to typically uneducated parents.

Table 1 reports the estimation results of the OLS and the quantile regressions for the saturated specifications including both individual and family background variables (first panel) and for the class and school covariates (second panel) $)^{2}$.

\footnotetext{
${ }^{2}$ The results for the individual and family background are qualitatively unaltered as the set of class and school covariates is included in or excluded from the quantile regressions.
} 
Table 1: Estimation Results - Individual Characteristics and Family Background

\begin{tabular}{|c|c|c|c|c|c|c|}
\hline $\begin{array}{l}\text { EXPLANATORY } \\
\text { VARIABLE } \\
\end{array}$ & OLS & $\begin{array}{c}10 \% \\
\text { QUANTILE } \\
\end{array}$ & $\begin{array}{c}25 \% \\
\text { QUANTILE } \\
\end{array}$ & $\begin{array}{c}50 \% \\
\text { QUANTILE } \\
\end{array}$ & $\begin{array}{c}75 \% \\
\text { QUANTILE } \\
\end{array}$ & $\begin{array}{c}90 \% \\
\text { QUANTILE } \\
\end{array}$ \\
\hline \multicolumn{7}{|c|}{ Individual and Family Background } \\
\hline Female & $\begin{array}{c}28.63 \\
(66.81)\end{array}$ & $\begin{array}{c}37.87 \\
(44.40)\end{array}$ & $\begin{array}{c}32.48 \\
(56.25)\end{array}$ & $\begin{array}{c}27.04 \\
(52.86)\end{array}$ & $\begin{array}{c}22.82 \\
(44.50)\end{array}$ & $\begin{array}{c}20.26 \\
(29.14)\end{array}$ \\
\hline Both Parents Work & $\begin{array}{c}7.78 \\
(16.93)\end{array}$ & $\begin{array}{c}11.52 \\
(12.49)\end{array}$ & $\begin{array}{c}9.53 \\
(15.32)\end{array}$ & $\begin{array}{c}7.25 \\
(13.22)\end{array}$ & $\begin{array}{c}6.02 \\
(10.96)\end{array}$ & $\begin{array}{c}4.94 \\
(6.62)\end{array}$ \\
\hline Intact Family & $\begin{array}{c}13.42 \\
(26.39)\end{array}$ & $\begin{array}{c}15.35 \\
(15.22)\end{array}$ & $\begin{array}{l}13.92 \\
(20.32)\end{array}$ & $\begin{array}{c}13.38 \\
(22.03)\end{array}$ & $\begin{array}{c}11.88 \\
(19.49)\end{array}$ & $\begin{array}{c}11.70 \\
(14.13)\end{array}$ \\
\hline Native Student & $\begin{array}{c}4.30 \\
(1.95)\end{array}$ & $\begin{array}{l}15.64 \\
(3.56)\end{array}$ & $\begin{array}{c}7.14 \\
(2.40)\end{array}$ & $\begin{array}{c}4.88 \\
(1.86)\end{array}$ & $\begin{array}{l}-5.19 \\
(-1.97)\end{array}$ & $\begin{array}{l}-9.17 \\
(-2.58)\end{array}$ \\
\hline Parents Foreign & $\begin{array}{l}-18.11 \\
(-7.56)\end{array}$ & $\begin{array}{l}-12.65 \\
(-2.65)\end{array}$ & $\begin{array}{l}-19.51 \\
(-6.04)\end{array}$ & $\begin{array}{l}-17.75 \\
(-6.21)\end{array}$ & $\begin{array}{l}-24.03 \\
(-8.40)\end{array}$ & $\begin{array}{l}-25.22 \\
(-6.52)\end{array}$ \\
\hline Second Generation & $\begin{array}{l}15.89 \\
(6.44)\end{array}$ & $\begin{array}{c}6.59 \\
(1.34)\end{array}$ & $\begin{array}{l}15.20 \\
(4.57)\end{array}$ & $\begin{array}{l}15.62 \\
(5.31)\end{array}$ & $\begin{array}{l}23.55 \\
(8.00)\end{array}$ & $\begin{array}{l}25.63 \\
(6.44)\end{array}$ \\
\hline Other Language at Home & $\begin{array}{c}-28.83 \\
(-35.19)\end{array}$ & $\begin{array}{c}-31.44 \\
(-19.23)\end{array}$ & $\begin{array}{c}-33.08 \\
(-29.98)\end{array}$ & $\begin{array}{c}-29.56 \\
(-30.23)\end{array}$ & $\begin{array}{l}-24.79 \\
(-25.26)\end{array}$ & $\begin{array}{c}-23.48 \\
(-17.63)\end{array}$ \\
\hline Parents Education & & & & & & \\
\hline No Schooling Mother & $\begin{array}{c}-43.71 \\
(-23.03)\end{array}$ & $\begin{array}{c}-44.32 \\
(-11.14)\end{array}$ & $\begin{array}{l}-44.79 \\
(-17.08)\end{array}$ & $\begin{array}{c}-46.43 \\
(-20.50)\end{array}$ & $\begin{array}{c}-44.74 \\
(-20.09)\end{array}$ & $\begin{array}{c}-40.92 \\
(-13.60)\end{array}$ \\
\hline Mother Compl. ISCED-1 & $\begin{array}{c}-24.67 \\
(-25.25)\end{array}$ & $\begin{array}{c}-24.14 \\
(-12.04)\end{array}$ & $\begin{array}{c}-26.22 \\
(-19.63)\end{array}$ & $\begin{array}{c}-24.26 \\
(-20.80)\end{array}$ & $\begin{array}{c}-25.43 \\
(-21.93)\end{array}$ & $\begin{array}{c}-24.52 \\
(-15.70)\end{array}$ \\
\hline Mother Compl. ISCED-2 & $\begin{array}{c}-17.75 \\
(-25.58)\end{array}$ & $\begin{array}{c}-15.21 \\
(-10.93)\end{array}$ & $\begin{array}{c}-18.41 \\
(-19.59)\end{array}$ & $\begin{array}{c}-17.97 \\
(-21.71)\end{array}$ & $\begin{array}{c}-19.17 \\
(-23.19)\end{array}$ & $\begin{array}{c}-19.01 \\
(-16.96)\end{array}$ \\
\hline Mother Compl. ISCED-3b & $\begin{array}{c}-9.39 \\
(-12.52)\end{array}$ & $\begin{array}{l}-6.84 \\
(-4.53)\end{array}$ & $\begin{array}{c}-10.77 \\
(-10.59)\end{array}$ & $\begin{array}{c}-9.59 \\
(-10.70)\end{array}$ & $\begin{array}{l}-10.71 \\
(-11.97)\end{array}$ & $\begin{array}{l}-10.38 \\
(-8.59)\end{array}$ \\
\hline No Schooling Father & $\begin{array}{c}-34.29 \\
(-18.20)\end{array}$ & $\begin{array}{l}-38.06 \\
(-9.70)\end{array}$ & $\begin{array}{c}-40.27 \\
(-15.50)\end{array}$ & $\begin{array}{c}-32.98 \\
(-14.67)\end{array}$ & $\begin{array}{c}-32.26 \\
(-14.59)\end{array}$ & $\begin{array}{c}-30.09 \\
(-10.12)\end{array}$ \\
\hline Father Compl. ISCED-1 & $\begin{array}{c}-16.14 \\
(-16.69)\end{array}$ & $\begin{array}{l}-14.95 \\
(-7.58)\end{array}$ & $\begin{array}{c}-16.56 \\
(-12.57)\end{array}$ & $\begin{array}{c}-17.31 \\
(-14.99)\end{array}$ & $\begin{array}{c}-15.69 \\
(-13.67)\end{array}$ & $\begin{array}{c}-15.72 \\
(-10.14)\end{array}$ \\
\hline Father Compl. ISCED-2 & $\begin{array}{c}-13.01 \\
(-18.72)\end{array}$ & $\begin{array}{l}-11.72 \\
(-8.43)\end{array}$ & $\begin{array}{c}-13.58 \\
(-14.47)\end{array}$ & $\begin{array}{c}-13.83 \\
(-16.68)\end{array}$ & $\begin{array}{c}-13.28 \\
(-15.98)\end{array}$ & $\begin{array}{c}-12.18 \\
(-10.81)\end{array}$ \\
\hline Father Compl. ISCED-3b & $\begin{array}{l}-6.31 \\
(-8.77)\end{array}$ & $\begin{array}{c}-3.56 \\
(-2.47)\end{array}$ & $\begin{array}{c}-5.71 \\
(-5.88)\end{array}$ & $\begin{array}{l}-7.07 \\
(-8.24)\end{array}$ & $\begin{array}{c}-8.61 \\
(-10.04)\end{array}$ & $\begin{array}{l}-9.49 \\
(-8.18)\end{array}$ \\
\hline Mother Tertiary Educ. & $\begin{array}{c}10.76 \\
(18.65)\end{array}$ & $\begin{array}{c}7.82 \\
(6.82)\end{array}$ & $\begin{array}{c}10.18 \\
(13.06)\end{array}$ & $\begin{array}{c}10.64 \\
(15.45)\end{array}$ & $\begin{array}{c}12.05 \\
(17.56)\end{array}$ & $\begin{array}{c}12.57 \\
(13.56)\end{array}$ \\
\hline Father Tertiary Educ. & $\begin{array}{c}16.74 \\
(29.25)\end{array}$ & $\begin{array}{c}16.94 \\
(14.73)\end{array}$ & $\begin{array}{l}16.46 \\
(21.19)\end{array}$ & $\begin{array}{c}16.90 \\
(24.74)\end{array}$ & $\begin{array}{c}16.28 \\
(23.95)\end{array}$ & $\begin{array}{c}16.81 \\
(18.34)\end{array}$ \\
\hline
\end{tabular}


Table 1 cont'd: Estimation Results - Class and School Characteristics

\begin{tabular}{|c|c|c|c|c|c|c|}
\hline $\begin{array}{l}\text { EXPLANATORY } \\
\text { VARIABLE } \\
\end{array}$ & OLS & $\begin{array}{c}10 \% \\
\text { QUANTILE }\end{array}$ & $\begin{array}{c}25 \% \\
\text { QUANTILE }\end{array}$ & $\begin{array}{c}50 \% \\
\text { QUANTILE } \\
\end{array}$ & $\begin{array}{c}75 \% \\
\text { QUANTILE } \\
\end{array}$ & $\begin{array}{c}90 \% \\
\text { QUANTILE } \\
\end{array}$ \\
\hline Class Size & $\begin{array}{c}1.96 \\
(57.07)\end{array}$ & $\begin{array}{c}2.29 \\
(28.90)\end{array}$ & $\begin{array}{c}2.16 \\
(43.97)\end{array}$ & $\begin{array}{c}1.93 \\
(47.25)\end{array}$ & $\begin{array}{c}1.64 \\
(41.28)\end{array}$ & $\begin{array}{c}1.50 \\
(28.64)\end{array}$ \\
\hline Homework Feedback & $\begin{array}{l}-1.75 \\
(-3.72)\end{array}$ & $\begin{array}{l}-1.91 \\
(-1.96)\end{array}$ & $\begin{array}{l}-3.15 \\
(-4.87)\end{array}$ & $\begin{array}{l}-1.69 \\
(-3.01)\end{array}$ & $\begin{array}{l}-2.10 \\
(-3.78)\end{array}$ & $\begin{array}{l}-2.07 \\
(-2.79)\end{array}$ \\
\hline Urban School & $\begin{array}{c}7.54 \\
(13.90)\end{array}$ & $\begin{array}{c}9.29 \\
(8.41)\end{array}$ & $\begin{array}{c}8.43 \\
(11.43)\end{array}$ & $\begin{array}{c}7.58 \\
(11.70)\end{array}$ & $\begin{array}{c}6.86 \\
(10.65)\end{array}$ & $\begin{array}{c}7.03 \\
(8.15)\end{array}$ \\
\hline Private School & $\begin{array}{l}14.79 \\
(18.34)\end{array}$ & $\begin{array}{l}16.44 \\
(9.80)\end{array}$ & $\begin{array}{c}13.37 \\
(12.10)\end{array}$ & $\begin{array}{c}12.15 \\
(12.62)\end{array}$ & $\begin{array}{c}12.55 \\
(13.11)\end{array}$ & $\begin{array}{l}13.53 \\
(10.50)\end{array}$ \\
\hline Selective School & $\begin{array}{c}19.83 \\
(32.16)\end{array}$ & $\begin{array}{c}20.03 \\
(15.60)\end{array}$ & $\begin{array}{c}20.39 \\
(24.00)\end{array}$ & $\begin{array}{c}19.63 \\
(26.67)\end{array}$ & $\begin{array}{c}19.29 \\
(26.59)\end{array}$ & $\begin{array}{c}19.41 \\
(19.84)\end{array}$ \\
\hline Poor Basic Conditions & $\begin{array}{c}-9.41 \\
(-13.04)\end{array}$ & $\begin{array}{l}-11.58 \\
(-8.10)\end{array}$ & $\begin{array}{c}-10.67 \\
(-11.01)\end{array}$ & $\begin{array}{c}-9.45 \\
(-10.97)\end{array}$ & $\begin{array}{l}-6.89 \\
(-7.97)\end{array}$ & $\begin{array}{l}-5.31 \\
(-4.54)\end{array}$ \\
\hline Regular Tests & $\begin{array}{c}4.57 \\
(7.60)\end{array}$ & $\begin{array}{c}3.67 \\
(3.05)\end{array}$ & $\begin{array}{c}4.53 \\
(5.59)\end{array}$ & $\begin{array}{c}5.23 \\
(7.29)\end{array}$ & $\begin{array}{c}5.22 \\
(7.30)\end{array}$ & $\begin{array}{c}4.23 \\
(4.37)\end{array}$ \\
\hline Teacher Shortage & $\begin{array}{c}-6.03 \\
(-10.32) \\
\end{array}$ & $\begin{array}{c}-6.52 \\
(-5.58)\end{array}$ & $\begin{array}{l}-7.58 \\
(-9.59) \\
\end{array}$ & $\begin{array}{l}-5.76 \\
(-8.27)\end{array}$ & $\begin{array}{l}-5.16 \\
(-7.41)\end{array}$ & $\begin{array}{l}-5.93 \\
(-6.30)\end{array}$ \\
\hline
\end{tabular}

Number of observations: 163,082. t-values in parentheses. See appendix Table A1 and text for a description of the variables. The reference category for the education levels is ISCED 3a, i.e. completed upper secondary education.

The overwhelming majority of the estimated coefficients is highly significant (the $99 \%$ critical value of the t-distribution is 2.576). The null hypothesis that the impact of the different education levels for the father and the mother equal each other is rejected for almost all quantiles by a sequence of Wald tests not reported in the table. Overall, it turns out that the estimates of the OLS mean regression paint a rather incomplete picture of the conditional distribution of the test score, since the impact of many covariates differs considerably throughout different quantiles. In the following, the estimation results of the different quantile regressions are considered in some more detail.

\section{Individual Characteristics and Family Background}

Females score considerably higher in the reading literacy test than males throughout all quantiles but especially in the lower part of the distribution. Surprisingly, students whose parents both work perform significantly better as well, with a quantitatively larger impact in the lower quantiles. Students living in an intact family, i.e. together with both parents, perform significantly better throughout all quantiles.

Being a non-citizen exhibits a significantly negative correspondence with reading literacy for the lowest quantile but displays a significantly positive coefficient estimate for the highest quantile. The mean and the median regression, however, report this variable as being insignificant. Second generation immigrants perform better throughout all quantiles but especially in the upper part of the distribution if compared to first-generation immigrant students. Students with parents who are non-citizens perform considerably worse especially in the upper quantiles. A very pronounced negative effect throughout all quantiles is exhibited for students who are regularly speaking another than the test 
language at home. Thus, in countries with a large immigrant population the education system has to work harder to achieve the same average performance scores as in a homogeneous society.

As all studies regarding the intergenerational transmission of education would have suggested, the educational background of the students' parents exhibits considerably predictive power. Correspondingly, a clear profile of reading performance emerges, with the score monotonously increasing in the education level of both parents. Specifically, the results suggest that and the impact of low education of the mother is more detrimental for student success than that of the father ${ }^{3}$. By, contrast, students with parents who completed tertiary education perform significantly better with stable coefficients throughout all quantiles. However, the positive impact of fathers' tertiary education is quantitatively more important than that of the mother. Consequently, it would be inappropriate to compare education systems without parental background of the current student generation.

Class and School Characteristics

Class size, albeit statistically significant, exhibits only a small positive impact on student success. Similarly, students receiving feedback to their homework, i.e. students whose homework is regularly graded or part of their marks perform slightly worse than average. Being enrolled in an urban and private school both exhibit positive, and sizeable impacts on student achievement. The results suggest that the effect of schools selecting their students on the basis of student performance, including placement tests is strongly positive whereas regular tests during the school year exhibit a rather small, albeit also positive impact. On the other hand, poor basic school conditions, e.g. lacking instructional material, and a shortage of teachers seem to exert a significantly negative impact on reading performance. This effect appears to be especially pronounced for the lower quantiles.

\section{Adjusted National Scores}

The estimation of quantile regressions involving three different specifications, (i) without any explanatory factors, (ii) including individual and family background, and (ii) also including school and class characteristics allows a re-assessment of national average scores. Figure 1 documents the the estimated scores arising from specification (iii) for the median quantile. In order to condense this information further, we estimated weighted averages of the national scores for three different specifications, relative to the US. This measure reveals how US students compare to randomly chosen students from the same performance quantile in the rest of the world. The weights are the shares of the population of country $i$ relative to the total population of all participating countries. Furthermore, we also report the weighted standard deviation around this average performance, corrected for first-stage estimation error (see HAISKEn-DeNEw AND SchmidT (1997) for a similar application to inter-industry wage differentials).

\footnotetext{
${ }^{3}$ The reference category for parental education is a completed ISCED-3a level, i.e. upper secondary education.
} 

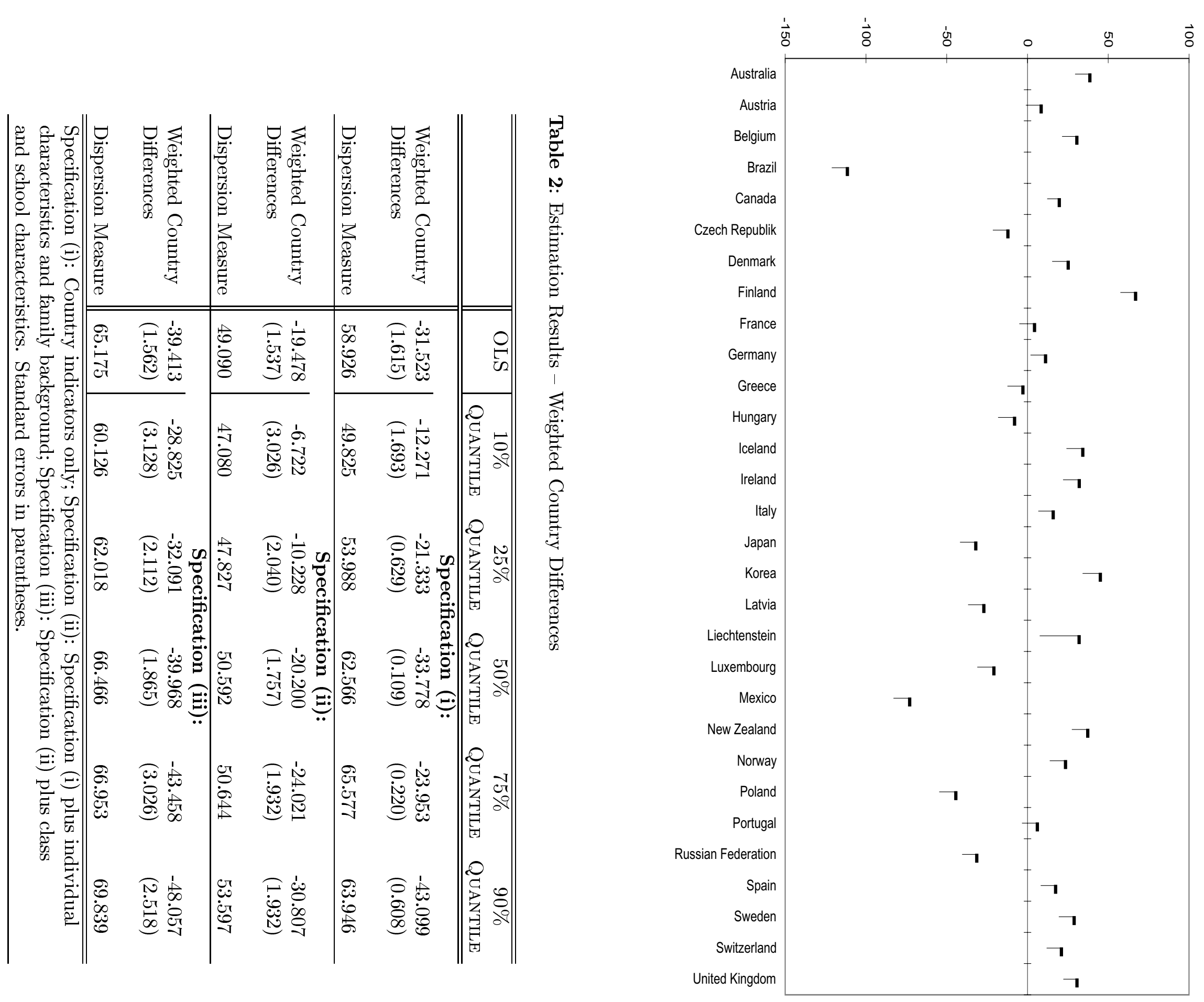

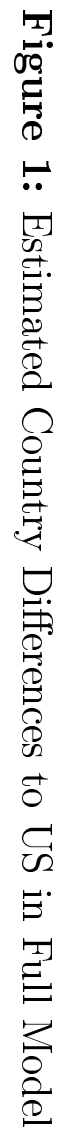


Table 2 reveals that on average as well as in all quantiles US students display better reading skills than randomly chosen students from other parts of the (participating) world. This difference is clearly more pronounced in higher quantiles. However, the corresponding dispersion measures document that these average results hide a large heterogeneity across countries (recall that the overall standard error in PISA 2000 was normalized to 100). A detailed inspection of the national scores (see also Figure 1) reveals that the summary measures are clearly dominated by the extremely poor performance of the rather large countries Brazil, Mexico, and Russia. Therefore, setting up alternative comparison groups for the performance of US students would clearly result in a less optimistic assessment.

The US education system currently serves a cohort of teenagers who started from a privileged position: in international comparison, the share of US students whose parents, and in particular whose mothers display a substantive education is high. Controlling for these individual and family background variables indeed reduces the advantage of the US across all quantiles. Given that Brazil, Mexico, and Russia are included in this comparison, this result is worrisome. In particular, at the top of the performance distribution, the US retains a sizeable advantage, but it almost vanishes completely for the lower quantiles.

In specifications (i) and (ii), education systems might exhibit low national score estimates whenever either or or several measurable aspects, such as teacher shortages, or intangible characteristics of the system are unfavorable. Specification (iii) allows the concentration to lie on the latter. Judging from the estimated national scores, controlling for tangible aspects of the school system leads to a larger advantage for the US. These estimates imply that, with a better organization of its education system the US would even lie more ahead in international comparison than is currently the case. Again, the US currently serves students in higher quantiles significantly more than those in the bottom of the performance distribution.

\section{Implications for Education Policy}

Our results qualify the intensely discussed OECD (2002) report on the PISA 2000 study, by an attempt to compare the performance of comparable students. Even after adjusting for a large set of background factors, significant differences between countries remain. The advantageous position of US students is especially pronounced in the upper part of the test score distribution. While those in the bottom of the distribution should be the source of serious discomfort. Overall, family background and school characteristics play a more important role for success in PISA 2000 than previously recognized in the debate.

Furthermore, from a policy perspective our results indicate that countries directly improve the performance of their school system by investing into tangible aspects of the system. In particular, school conditions including teacher provision account for a sizeable fraction of student's individual success in PISA 2000. However, for exhaustive policy advice it is necessary to collect even more information. To paint a complete picture of institutional differences and their impact would require for more extensive background 
information, most of all repeated information on the same set of students. This is, unfortunately, not the planned design of the next PISA waves. Moreover, it is indispensable to evaluate the impact of institutional changes and policy interventions in the education sector with an emphasis on comparing genuinely comparable students.

Thus, school quality apparently does matter. Moreover, it seems to be the students in the bottom of the performance distribution who suffer most if their education environment is lacking. Consequently, before policy makers should be seeking for deep philosophical distinctions underlying the education systems in the more successful countries of PISA 2000, they should turn to improvements in the tangible aspects of the system. 


\section{References}

Barro, Robert J. and Jong-Wha Lee (2001) Schooling Quality in a Cross-Section of Countries. Economica, 68, 465-488.

Borjas, George J. (1985), Assimilation, Changes in Cohort Quality, and the Earnings of Immigrants. Journal of Labor Economics, 3, 463-489.

Card, David and Alan B. Krueger (1996), Labor Market Effects of School Quality: Theory and Evidence. In: Burtless, GARY (ED.), Does Money Matter? The Effect of School Resources on Student Achievement and Adult Success., Washington D.C.: Brookings Institution, 97-140.

Card, David and Alan B. Krueger (1992), Does School Quality Matter? Returns to education and the Characteristics of Public Schools in the United States. Journal of Political Economy, 100, 1-40.

Chamberlain, Gary (1994), Quantile Regression, Censoring, and the Structure of Wages. In: Sims, Christopher A. (ED.), Advances in Econometrics - Sixth World Congress., Cambridge: Cambridge University Press, 171-209.

Coleman, J.S., E.Q. Campbell, C.J. Hobson et Al. (1966), Equality of Educational Opportunity. Washington, D.C.: US Government Printing Office.

Eide, Eric and Mark H. Showalter (1998), The Effect of School Quality on Student Performance: A Quantile Regression Approach. Economics Letters, 58, 345-350.

Fitzenberger, Bernd (1999), Wages and Employment Across Skill Groups. Heidelberg: Physica-Verlag.

Haisken-Denew, John P. and Christoph M. Schmidt (1997), Inter-Industry and Inter-Region Differentials: Mechanics and Interpretation. The Review of Economics and Statistics, 79, 516-521.

Hambleton, Ronald K. and H. Swaminathan (1984), Item Response Theory Principles and Applications. Boston: Kluwer.

Hanushek, Eric A. (1986) The Economics of Schooling: Production and Efficiency in Public Schools. Journal of Economic Literature, 24, 1141-1177.

Koenker, Roger and Gilbert Bassett (1978), Regression Quantiles. Econometrica, 46, 33-50.

Levin, Jesse (2001), Where the Reductions Count: A Quantile Regression Analysis of Effects of Class Size and Peer Effects on Scholastic Achievement. Empirical Economics, 26, 241-246. 
Organisation for Economic Co-Operation and Development (OECD) (2002), Knowledge and Skills for Life: First Results from PISA 2000. Paris.

Warm, Thomas A. (1989), Weighted Likelihood Estimation of Ability in Item Response Theory. Psychometrika, 54, 427-450. 


\section{Appendix}

Table A1: Description of Variables

\begin{tabular}{|c|c|}
\hline VARIABLE & DESCRIPTION \\
\hline Reading Score & Difficulty-adjusted test score in the reading literacy test \\
\hline \multicolumn{2}{|c|}{ Demographic and Family Background } \\
\hline Female & 1 if student is female; 0 otherwise \\
\hline Both Parents Work & $\begin{array}{l}1 \text { if student's mother and father are working full-time } \\
\text { or part-time; } 0 \text { otherwise }\end{array}$ \\
\hline Intact Family & 1 if student lives together with both parents; 0 otherwise \\
\hline Native Student & $\begin{array}{l}1 \text { if student is a citizen of the country of residence; } \\
0 \text { otherwise }\end{array}$ \\
\hline Parents Foreign & $\begin{array}{l}1 \text { if student's parents are non-citizens of the country of } \\
\text { residence; } 0 \text { otherwise }\end{array}$ \\
\hline Second Generation & $\begin{array}{l}1 \text { if student is a second-generation migrant in the } \\
\text { country of residence; } 0 \text { otherwise }\end{array}$ \\
\hline Diff. Language at Home & $\begin{array}{l}1 \text { if the regular language at student's home is different } \\
\text { from the respective test language; } 0 \text { otherwise }\end{array}$ \\
\hline \multicolumn{2}{|l|}{ Parents Education } \\
\hline No Schooling Mother & 1 if student's mother did not attend school; 0 otherwise \\
\hline No Schooling Father & 1 if student's father did not attend school; 0 otherwise \\
\hline Mother ISCED-1 & $\begin{array}{l}1 \text { if student's mother completed primary education; } \\
0 \text { otherwise }\end{array}$ \\
\hline Father ISCED-1 & $\begin{array}{l}1 \text { if student's father completed primary education; } \\
0 \text { otherwise }\end{array}$ \\
\hline Mother ISCED-2 & $\begin{array}{l}1 \text { if student's mother completed lower secondary } \\
\text { education; } 0 \text { otherwise }\end{array}$ \\
\hline Father ISCED-2 & $\begin{array}{l}1 \text { if student's father completed lower secondary } \\
\text { education; } 0 \text { otherwise }\end{array}$ \\
\hline Mother ISCED-3b & $\begin{array}{l}1 \text { if student's mother completed secondary education; } \\
0 \text { otherwise }\end{array}$ \\
\hline Father ISCED-3b & $\begin{array}{l}1 \text { if student's father completed secondary education; } \\
0 \text { otherwise }\end{array}$ \\
\hline Mother ISCED-3a & $\begin{array}{l}1 \text { if student's mother completed upper secondary education; } \\
0 \text { otherwise }\end{array}$ \\
\hline Father ISCED-3a & $\begin{array}{l}1 \text { if student's father completed upper secondary education; } \\
0 \text { otherwise }\end{array}$ \\
\hline Mother Tertiary Educ. & $\begin{array}{l}1 \text { if student's mother completed tertiary education; } \\
0 \text { otherwise }\end{array}$ \\
\hline Father Tertiary Educ. & $\begin{array}{l}1 \text { if student's father completed tertiary education; } \\
0 \text { otherwise }\end{array}$ \\
\hline \multicolumn{2}{|c|}{ School-Related Information } \\
\hline Class Size & Average number of students in class \\
\hline Homework Feedback & $\begin{array}{l}1 \text { if students homework is regularly graded or } \\
\text { if homework is part of his/her marks; } 0 \text { otherwise }\end{array}$ \\
\hline
\end{tabular}


Table A1 cont'd: Description of Variables

\begin{tabular}{|c|c|}
\hline VARIABLE & DESCRIPTION \\
\hline$\overline{\text { Urban School }}$ & $\begin{array}{l}1 \text { if the school is located in a city of more than } \\
100,000 \text { inhabitants; } 0 \text { otherwise }\end{array}$ \\
\hline Private School & 1 if the school is a private school; 0 otherwise \\
\hline Selective School & $\begin{array}{l}1 \text { if admission to school is based on student's } \\
\text { record of academic performance including placement } \\
\text { tests; } 0 \text { otherwise }\end{array}$ \\
\hline Poor Basic Conditions & $\begin{array}{l}1 \text { if school is suffering from poor conditions of } \\
\text { building structure, poor heating/cooling/lighting systems, lack of } \\
\text { instruction space or lack of instruction material; } \\
0 \text { otherwise }\end{array}$ \\
\hline Regular Tests & $\begin{array}{l}1 \text { if students are assessed four or more times a year } \\
\text { using standardized or teacher-developed tests; } 0 \text { otherwise }\end{array}$ \\
\hline Teacher Shortage & $\begin{array}{l}1 \text { if school suffers from a teacher shortage } \\
\text { or test language teacher shortage; } 0 \text { otherwise }\end{array}$ \\
\hline
\end{tabular}

Number of observations: 163,082. All explanatory variables except class size are categorical. Source:OECD (2002). 
Table A2: Summary Statistics

\begin{tabular}{l|cc}
\hline \hline VARIABLE & MEAN & STANDARD ERROR \\
\hline \hline Reading Score & 502.921 & 98.098 \\
Explanatory Variables & & \\
Australia & 0.031 & 0.173 \\
Austria & 0.028 & 0.165 \\
Belgium & 0.039 & 0.193 \\
Brasil & 0.029 & 0.167 \\
Canada & 0.171 & 0.376 \\
Czech Republic & 0.031 & 0.174 \\
Denmark & 0.023 & 0.150 \\
Finland & 0.029 & 0.168 \\
France & 0.027 & 0.163 \\
Germany & 0.030 & 0.170 \\
Greece & 0.027 & 0.163 \\
Hungary & 0.029 & 0.168 \\
Iceland & 0.020 & 0.140 \\
Ireland & 0.023 & 0.151 \\
Italy & 0.030 & 0.171 \\
Japan & 0.030 & 0.172 \\
Korea & 0.026 & 0.158 \\
Latvia & 0.022 & 0.148 \\
Liechtenstein & 0.002 & 0.043 \\
Luxembourg & 0.019 & 0.137 \\
Mexico & 0.026 & 0.158 \\
New Zealand & 0.022 & 0.146 \\
Norway & 0.025 & 0.155 \\
Poland & 0.020 & 0.142 \\
Portugal & 0.027 & 0.162 \\
Russia & 0.039 & 0.195 \\
Spain & 0.036 & 0.187 \\
Sweden & 0.026 & 0.158 \\
Switzerland & 0.036 & 0.185 \\
United Kingdom & 0.056 & 0.229 \\
USA & 0.021 & 0.145 \\
Female & 0.504 & 0.500 \\
Both Parents Work & 0.595 & 0.491 \\
Intact Family & 0.754 & 0.431 \\
Native Student & 0.907 & 0.290 \\
Parents Foreign & 0.202 & 0.402 \\
Second Generation & 0.119 & 0.324 \\
Other language at home & 0.151 & 0.358 \\
\hline \hline Number of observations: & \\
\hline
\end{tabular}


Table A2 cont'd: Summary Statistics

\begin{tabular}{l|cc}
\hline \hline VARIABLE & MEAN & STANDARD ERROR \\
\hline \hline No Schooling Mother & 0.017 & 0.128 \\
Mother Completed ISCED-1 & 0.092 & 0.289 \\
Mother Completed ISCED-2 & 0.171 & 0.376 \\
Mother Completed ISCED-3b & 0.153 & 0.360 \\
No Schooling Father & 0.017 & 0.128 \\
Father Completed ISCED-1 & 0.089 & 0.285 \\
Father Completed ISCED-2 & 0.167 & 0.373 \\
Father Completed ISCED-3b & 0.169 & 0.375 \\
Mother Tertiary Education & 0.286 & 0.452 \\
Father Tertiary Education & 0.301 & 0.459 \\
Class Size & 24.899 & 8.073 \\
Homework Feedback & 0.405 & 0.491 \\
Urban School & 0.271 & 0.445 \\
Private School & 0.124 & 0.330 \\
Selective School & 0.267 & 0.442 \\
Poor Basic Conditions & 0.115 & 0.319 \\
Regular Tests & 0.727 & 0.446 \\
Teacher Shortage & 0.188 & 0.390 \\
\hline \hline Number of observations: 163,$082 ;$ Source:OECD (2002). \\
\hline
\end{tabular}




\section{IZA Discussion Papers}

\begin{tabular}{|c|c|c|c|c|}
\hline No. & Author(s) & Title & Area & Date \\
\hline 528 & $\begin{array}{l}\text { P. Manzini } \\
\text { M. Mariotti }\end{array}$ & $\begin{array}{l}\text { Arbitration and Mediation: An Economic } \\
\text { Perspective }\end{array}$ & 3 & 07/02 \\
\hline 529 & $\begin{array}{l}\text { J. M. Orszag } \\
\text { D. Snower }\end{array}$ & Incapacity Benefits and Employment Policy & 3 & $07 / 02$ \\
\hline 530 & $\begin{array}{l}\text { M. Karanassou } \\
\text { D. Snower }\end{array}$ & Unemployment Invariance & 3 & $07 / 02$ \\
\hline 531 & $\begin{array}{l}\text { M. Karanassou } \\
\text { H. Sala } \\
\text { D. Snower }\end{array}$ & $\begin{array}{l}\text { Unemployment in the European Union: A } \\
\text { Dynamic Reappraisal }\end{array}$ & 3 & $07 / 02$ \\
\hline 532 & $\begin{array}{l}\text { J. M. Orszag } \\
\text { D. Snower }\end{array}$ & $\begin{array}{l}\text { From Unemployment Benefits to Unemployment } \\
\text { Accounts }\end{array}$ & 3 & $07 / 02$ \\
\hline 533 & $\begin{array}{l}\text { S. Fölster } \\
\text { R. Gidehag } \\
\text { M. Orszag } \\
\text { D. Snower }\end{array}$ & Assessing Welfare Accounts & 3 & $07 / 02$ \\
\hline 534 & $\begin{array}{l}\text { A. Lindbeck } \\
\text { D. Snower }\end{array}$ & The Insider-Outsider Theory: A Survey & 3 & $07 / 02$ \\
\hline 535 & $\begin{array}{l}\text { P. Manzini } \\
\text { D. Snower }\end{array}$ & $\begin{array}{l}\text { Wage Determination and the Sources of } \\
\text { Bargaining Power }\end{array}$ & 3 & $07 / 02$ \\
\hline 536 & $\begin{array}{l}\text { M. Orszag } \\
\text { D. Snower }\end{array}$ & Pension Taxes versus Early Retirement Rights & 3 & $07 / 02$ \\
\hline 537 & $\begin{array}{l}\text { J. M. Orszag } \\
\text { D. Snower }\end{array}$ & $\begin{array}{l}\text { Unemployment Vouchers versus Low-Wage } \\
\text { Subsidies }\end{array}$ & 3 & 07/02 \\
\hline 538 & $\begin{array}{l}\text { M. Orszag } \\
\text { D. Snower }\end{array}$ & The Pension Transfer Program & 3 & $07 / 02$ \\
\hline 539 & $\begin{array}{l}\text { Y.-F. Chen } \\
\text { D. Snower } \\
\text { G. Zoega }\end{array}$ & $\begin{array}{l}\text { Labour-Market Institutions and Macroeconomic } \\
\text { Shocks }\end{array}$ & 3 & $07 / 02$ \\
\hline 540 & $\begin{array}{l}\text { G. S. Epstein } \\
\text { A. Kunze } \\
\text { M. E. Ward }\end{array}$ & $\begin{array}{l}\text { High Skilled Migration and the Exertion of Effort } \\
\text { by the Local Population }\end{array}$ & 1 & $08 / 02$ \\
\hline 541 & $\begin{array}{l}\text { B. Cockx } \\
\text { M. Dejemeppe }\end{array}$ & $\begin{array}{l}\text { Do the Higher Educated Unemployed Crowd Out } \\
\text { the Lower Educated Ones in a Competition for } \\
\text { Jobs }\end{array}$ & 2 & 08/02 \\
\hline 542 & M. Frölich & Programme Evaluation with Multiple Treatments & 6 & $08 / 02$ \\
\hline 543 & $\begin{array}{l}\text { J. Darby } \\
\text { R. A. Hart }\end{array}$ & $\begin{array}{l}\text { Wages, Productivity, and Work Intensity in the } \\
\text { Great Depression }\end{array}$ & 5 & $08 / 02$ \\
\hline 544 & $\begin{array}{l}\text { P. Portugal } \\
\text { A. R. Cardoso }\end{array}$ & $\begin{array}{l}\text { Disentangling the Minimum Wage Puzzle: An } \\
\text { Analysis of Worker Accessions and Separations }\end{array}$ & 3 & $08 / 02$ \\
\hline 545 & $\begin{array}{l}\text { M. Fertig } \\
\text { C. M. Schmidt }\end{array}$ & $\begin{array}{l}\text { The Role of Background Factors for Reading } \\
\text { Literacy: Straight National Scores in the PISA } \\
2000 \text { Study }\end{array}$ & 6 & $08 / 02$ \\
\hline
\end{tabular}

